\title{
Botany
}

\section{Trichomycete prevalence in Thomas Brook, Nova Scotia exposed to different levels of human activity.}

\begin{tabular}{|r|l|}
\hline Journal: & Botany \\
\hline Manuscript ID & cjb-2021-0053.R1 \\
\hline Manuscript Type: & Article \\
\hline Date Submitted by the \\
Author: & 11-Jun-2021 \\
\hline Complete List of Authors: & Strongman, Doug; Saint Marys University \\
\hline Keyword: & $\begin{array}{l}\text { Insect gut fungi, Kickellomycotina, stream water quality, taxonomy, } \\
\text { trichomycete ecology }\end{array}$ \\
\hline $\begin{array}{r}\text { Is the invited manuscript for } \\
\text { consideration in a Special } \\
\text { Issue? : }\end{array}$ & Not applicable (regular submission) \\
\hline
\end{tabular}

\section{SCHOLARONE ${ }^{m}$ \\ Manuscripts}


Trichomycete prevalence in Thomas Brook, Nova Scotia exposed to different levels of human activity.

D.B. Strongman, Halifax, NS, B3L 1S2

e-mail: dougstrongman@gmail.com

Corresponding author: Doug Strongman e-mail: dougstrongman@gmail,com Tel: 902-4534287 


\begin{abstract}
The Thomas Brook in the Annapolis Valley, Nova Scotia was the focus of an Agriculture and Agri-Food Canada watershed evaluation of beneficial management practices (WEBs) project from 2004-2008. The stream is impacted by human activities along its course with residential influences and farming operations. The water quality in Thomas Brook was assessed in 2006 and the current study done in 2011-2012 used the same standard invertebrate metrics to measure water quality. This project also examined the prevalence of gut endosymbionts (trichomycetes) in aquatic invertebrates to determine if water quality affects this community of obligate microorganisms in their hosts. The water quality was improved in Thomas Brook in 2011/2012 compared to that measured in the earlier study. There were 34 taxa of trichomycetes recorded in benthic insects in the stream, including 2 new species. The trichomycete community was rich in dipteran hosts (midges and black fly larvae) but the prevalence of gut fungi in ephemeropteran (mayfly) nymphs in the system was low, perhaps due to impact of human activities on water quality.
\end{abstract}

Keywords: Insect gut fungi, Kickellomycotina, stream water quality, taxonomy, trichomycete ecology. 


\section{Introduction}

The insect intestinal tract provides a unique microhabitat for a complex array of microorganisms. Trichomycetes are a group of obligate, commensalistic fungi and protists that are found in the gut of many types of arthropods, including freshwater aquatic insects (Lichtwardt 1986, Lichtwardt et al. 2001). Much of the published information on trichomycetes to date documents the presence and describes new species found in hosts from lotic (stream) environments. There is some information about these microbes from hosts living in lentic habitats (ponds, lakes, phytotelm, and pitcher plants) (Lichtwardt 1994, Reeves, 2004, William and Strongman 2013c). Fewer authors have incorporated ecological data for trichomycetes into their studies. Nelder et al. (2006) and McCreadie et al, (2011) recorded prevalence and distribution of trichomycetes in black fly larvae at different geographical scales and speculated about the factors (water quality, mechanisms for dispersal) that may drive the patterns seen. Lichtwardt (1995) published information on the biogeography of trichomycetes and suggested that there were barriers for the dispersal of certain species while others enjoyed a nearly global distribution. Several species such as Harpella tica Lichtw., Harpella amazonica Ríos-Velásquez, Lichtw., Hamada \& Alencar, and Smittium brasiliense Alencar, Lichtw., Ríos-Velásquez \& Hamada, for example, have only been described from tropical regions (Lichtwardt 2012a) and there is evidence for speciation events within the trichomycetes to have produced sister species among trichomycetes found in Europe compared to North America (Lichtwardt 2012b, White et al. 2018). The use of insects as bioindicators of water quality is well known (Merritt and Cummins 1996) so it stands to reason that since trichomycetes are exploiting the insect gut where ingested food is concentrated that they may be impacted by pollutants even before the insect hosts. There is interest in trichomycete ecology and how human activities may impact the 
aquatic system and what, if any, effects this may have on the prevalence and diversity of trichomycete species in the insect hosts but there are very little published data on these aspects of trichomycete ecology. Wilson et al. (2014) reported on the effects of agricultural activity on trichomycete prevalence in black flies. They showed that fungal density and prevalence was lower in hosts exposed to fungicide but were not able to demonstrate direct causality due to other parameters such as temporal and site differences in fungal colonization of insect guts (Wilson et al. 2014). A new species, Smittium gravimetallum Lichtw. Ferrington \& Hayford, was described, the only fungus collected from only one of several chironomid species present at a site contaminated with heavy metal pollutants (Ferrington et al. 2000).

Thomas Brook is a small stream which is part of the Cornwallis River watershed located in the Annapolis Valley, Nova Scotia, Canada (Fig. 1A). It originates from ground water sources at the top of the North Mountain and flows downhill through areas that are differentially impacted by humans, firstly in a residential area, then farming operations (a dairy farm and crop cultivation) and pastureland at the base where the brook flows into the Cornwallis River. Brisbois et al. (2008) assessed the water quality at points along Thomas Brook impacted to different degrees using physical water quality measures as well as macrobenthic invertebrate collections as bioindicators of water quality over the span of a year. They found water quality in the system was excellent to fair, depending on the influence of human activity as well as the time of year (Brisbois et al. 2008). The invertebrate metrics used in the Brisbois study were \%EPT (Ephemeroptera, Plecoptera and Trichoptera), \%Chironomidae and Hilsenhoff’s Family Biotic Index (FBI). Taxa richness (species or families collected) was also given in Brisbois et al. (2008). These are common means to indirectly assess water quality. Lydy et al (2000) compared a number of indices and measures of water quality after wastewater treatment and found the FBI 
was good at reflecting changes in water quality. A review of 78 macroinvertebrate and fish-based indices by Herman and Nejadhashemi (2015) showed the FBI and \%EPT were good techniques to measure changes in water quality.

I present in this report some of the same insect metrics used by Brisbois at 4 sites along the course of Thomas Brook, including one site used in that study, over 16 months. Trichomycete community structure within the insects collected for the bioindicator metrics was also recorded. Two new species are described and several new geographic distribution records for the trichomycetes. The richness and prevalence of trichomycetes were compared for mayflies and dipterans that were found year-long at the four sites in Thomas Brook.

\section{Materials and Methods}

The Thomas Brook system was part of the WEBs project conducted by Agriculture Canada which included some development of best practices for farms in the area and remediation projects along the brook to improve water quality in the system (AAFC \# 10317E 2008). These efforts took place from 2004-2008, prior to invertebrate and sampling reported here from 2011 and 2012. Water quality was assessed in this system by Brisbois et al. (2008) by measuring physical parameters and invertebrate sampling to calculate the Family Biotic Index (FBI) described by Hilsenhoff at the top, middle and lower end of the Thomas Brook system. The results from Thomas Brook were compared to another nearby site (Sharpe Brook) which was in a wooded area with little human activity (Brisbois et al. 2008).

The results reported in my study were from benthic invertebrates collected from 4 sites (Fig 1B) in the Thomas Brook system. The origin of Thomas Brook (Site 1) was a shallow (3-5 $\mathrm{cm}$ deep) stream flowing over a rocky bottom with aquatic vegetation and the riparian area consisted of a closed canopy of mature mixed conifer and hardwood trees and a 
woody/herbaceous plant understory. Sites 2 and 3 were located about halfway along the system (Fig. 1B) and were in an agricultural area where corn and vegetables were produced. Site 2 was a lotic stream up to $1 \mathrm{~m}$ in depth with sandy banks and woody debris. This site also had a closed canopy of mixed trees and woody shrubs and grasses along the banks. Site 3 was an irrigation pond providing water for surrounding crop fields with little overhanging vegetation. Site 4 was located near the end of Thomas Brook and was a ditch running through a field where forage was grown. The stream depth varied according to season from 2-3 $\mathrm{m}$ of fast flowing water after large rain events and snow melt to $<1 \mathrm{~m}$ in the summer months. The riparian zone was open with grasses overhanging the stream and the adjacent forage crop area was fertilized with manure in the spring.

Collections of invertebrates at the four sites were made approximately monthly from April 2011 to Aug 2012, except from the pond in Jan 2012 due to ice cover. Collections were made with a D-net (gape size $30 \mathrm{~cm}$, mesh $0.5 \mathrm{~mm}$ ) by disturbing the surface of the stream with the feet while dragging the net behind (kick sampling). About a $50 \mathrm{~m}$ stretch of stream was sampled this way at Sites 1, 2 and 4. The pond was sampled by thrusting or dragging the D-net 20 times into the sediments on the edge of the pond where it was sandy and in areas with vegetation. The contents of the D-net for each sample were put in a plastic bag and transported to the lab for sorting and identification. All specimens collected were counted and identified to order or family. Insects from herbivorous taxa were dissected. All individuals from each Family were dissected if fewer than 25 , otherwise up to 25 were dissected. The hindgut and, for dipterans the peritrophic matrix also, were removed in water drops in glass Petri plates on the transmitted light base of a stereomicroscope then mounted in water on microscope slides. These preparations were examined under phase contrast or differential interference contrast 
illumination on a compound microscope to detect and identify trichomycetes. Digital images of characters required for identification of the trichomycetes were taken. Insect identifications were done using keys found in Merritt and Cummins (1996) and the Lucid Keys for the trichomycetes (Lichtwardt 2004) provided identifications of the trichomycetes. After digital images were acquired, the slides were stained with lactophenol cotton blue, cleaned and the coverslips sealed with clear fingernail polish. Type slides for the new species described here were deposited at the National Mycological Herbarium, Agriculture and Agri-Food Canada, Ottawa, ON (DAOM). The techniques for invertebrate collection and preparation of slides for identification and voucher of trichomycetes are described in (Lichtwardt 1986, Lichtwardt et al. 2001).

Insect metrics compiled followed those used by Brisbois et al. (2008) and included \%EPT (Ephemeroptera, Plecoptera and Trichoptera), \%Chironomidae and Hilsenhoff’s Family Biotic Index (FBI). Hilsenhoff (1988) also provides a numerical range based on the FBI that describes water quality (water quality evaluation, WQE). Richness (species or families collected) were also given in Brisbois et al. (2008) and the number of taxa identified (mostly families) in my collections are reported here. The method for calculating these measures is given in Hilsenhoff (1988) and Brisbois et al. (2008).

\section{Results}

\section{Taxonomy}

Smittium scrobense Strongman sp. nov. Fig. 2 A-D. Mycobank \# MB838925

TYPUS: Lactophenol cotton blue stained thalli and trichospores, on a microscope slide (TB5-3), collected from the hindgut of midge (Chironomidae) larvae in Thomas Brook near Berwick, Nova Scotia, Canada on 24 May 2011 (DAOM 749216, holotype) 
ETYMOLOGY: From the Latin "scrobis" = ditch, in reference to the habitat where midges were collected.

DESCRIPTION: Thalli sparsely branched, verticilliate in larger thalli. Young thalli with a bulbous basal cell $(4.5-5.5 \mu \mathrm{m})$, up to $9 \mu \mathrm{m}$ with mucilage in larger thalli. Trichospores produced from most cells on young thalli and from terminal fertile branches on older thalli, $2-8$ per branch. Trichospores ellipsoidal, $20-27 \times 3.5-4.5 \mu \mathrm{m}$ with a slight medial swelling, collar 2-4 × 3-3.5 $\mu \mathrm{m}$ cylindrical to slightly tapered, generative cells generally shorter than the trichospores. Zygospores not found. Attached to the hindgut lining of midge larvae (Chironomidae). ECOLOGY AND DISTRIBUTION: This species was recorded from the hindgut of midge larvae collected from Thomas Brook Site 4 on 24 May 2011, Site 2 on 22 July 2012, and Site 3 (irrigation pond) on 24 May 2011 and 22 July 2012.

COMMENTS: Smittium is the most speciose genus in the Harpellales so to differentiate among them, features other than simple trichospore and zygospore dimensions are required. Smittium scrobense has trichospores that overlap with four other species but features of the trichospores or thallus differ from these comparable species (Lichtwardt 2004). Smittium gronthidium Strongman \& M.M. White has a large knobby holdfast and the trichospore length is variable (15-31 (-40) $\mu \mathrm{m})$ (Lichtwardt 2004), S. scrobense has a small discrete holdfast with secreted material and the trichospores are more uniform than those seen in S. gronthidium. Smittium rarum Lichtw. trichospores overlap in size but the collar in this species is shorter than in $S$. scrobense. Smittium sparsum also has a shorter collar and fewer trichospores per fertile branch compared to $S$. scrobense. The thallus in Smittium gravimetallum is more strongly verticilliate than S. scrobense, the trichospores are longer and the spore collar is shorter than on the trichospores of S. scrobense (Lichtwardt 2004). 
Stachylina stagnicola sp. nov. Fig. 3 A-B.

Mycobank \# MB838926

TYPUS: Microscope slide TBP-1 containing thalli and spores stained with lactophenol-cotton blue collected on the peritrophic matrix of a midge larva from an irrigation pond (Site 3) flowing into Thomas Brook on 5 Jul 2011 near Berwick, Nova Scotia, Canada (DAOM 749217, holotype).

The type slide has thalli and trichospores of the larger-spored Stachylina subgrandis M.M. White $\&$ Strongman on the same peritrophic matrix, as well as extensive thalli and trichospores of Smittium colboi Strongman in the hindgut on the same slide.

ETYMOLOGY: From the Latin "stagnum" meaning pond, referring to the habitat where the host larva was collected.

DESCRIPTION: Thalli 65-85 $\mu \mathrm{m}$ long, slightly tapered at the base, attached to the peritrophic matrix by a spherical blob of amorphous material. Four trichospores per thallus, ellipsoidal, 20$34 \times 5-9 \mu \mathrm{m}$ with a short $(1-2 \mu \mathrm{m})$ cylindrical collar, generative cells about as long as the trichospores. No zygospores found. Attached to the peritrophic matrix of midge (Chironomidae) larvae.

ECOLOGY AND DISTRIBUTION: This species was in midge larvae collected from the irrigation pond (Site 3) on 4 Jun and 5 July 2011 and from midge larvae from Site 1 on 6 Sep 2011. COMMENTS: Stachylina is the second most speciose genus of Harpellales, after Smittiium (Lichtwardt 2004). Stachylina species present more challenges using morphology to describe and differentiate among the species because they have a simple unbranched thallus and have few other characters typically used for comparison in more complex genera. In addition, conjugation which precedes sexual spore production is often seen in species of Stachylina but zygospores have only been described from cultures of Stachylina pedifer M.C. Williams \& Lichtw. by Beard 
and Adler (2003). Of the Stachylina species that overlap in trichospore dimensions with $S$. stagnicola, S. acutobasilaris M.M. White \& Lichtw., S. thaumaleidarum Lichtw. \& M.C. Williams and S. longa Léger \& Gauthier all lack a collar (Lichtwardt 2004), as in S. stagnicola trichospores. Stachylina lentica M.M. White \& Lichtw. usually only has two trichospores per thallus and they are longer than trichospores of S. stagnicola. Stachylina tanysoma R.T. William \& Strongman and S. uranus R.T. William \& Strongman trichospores overlap in size but these species have many more spores per thallus produced from very short generative cells (Lichtwardt 2004), which differentiate them easily from S. stagnicola. The trichospores of S. platensis López Lastra, Lichtw. \& Ferrington overlap in size but the trichospores of this species are more tapered (ellipsoidal) than those in S. stagnicola (Lichtwardt 2004).

Including the two new species there were 34 trichomycete species collected for all sites and collection dates combined in this study (Table 1). Four species are new records for Canada: Enterobryus euryuri Lichtw., Pennella angustispora Lichtw. (Fig. 4 C, D, E.), Pseudoharpella arcolamylica Ferrington, M.M. White \& Lichtw. (Fig. 4 F, G, H.) and Smittium caribense L.G. Valle \& Cafaro (Fig. 4 A and B). Genistellospora homothallica Lichtw. and Smittium alpinum Lichtw. were previously collected in Canada only from Algonquin Park, ON (Strongman and White 2008) and Graminella microspora S.T. Moss \& Lichtw. is known from one other collection in Canada, at Gros Morne National Park, NF (Strongman 2010).

\section{Insect metrics and water quality assessment}

The mean \%EPT from 3 stream sites in Thomas Brook was $63 \%$ compared to $35.7 \%$ for the three sites in Thomas Brook sampled by Brisbois et al. (2008). Percentage EPT for each of the Thomas Brook sites over the 16-month collection period averaged $71.3 \%, 54.7 \%$ and $62 \%$ for Sites 1, 2 and 4 respectively (Fig. 5). Chironomids are often dominant compared to EPT taxa 
in poor water quality (Crawford and Lenat 1989). The average \%Chironomidae in my collections was $14.6 \%$; site 2 had the highest $\%$ Chironomidae (30.4\%) but they were relatively low at site 1 $(11.2 \%)$ and site $4(7.2 \%)$ and $13.8 \%$ in the pond (site 3) (Fig. 5). Brisbois et al. (2008) reported higher overall abundance of chironomids, an average of $39 \%$ at the sites where invertebrates were collected. Invertebrate taxa richness overall at the three stream sites in Thomas Brook was similar over the 16-month study with 41, 45 and 38 taxa present at sites 1,2 and 4. An average of 15.7 taxa were reported from all sites in Thomas Brook by Brisbois et al (2008), much lower than the richness I recorded in the stream.

The Brisbois study included a site (Sharpe Brook), also located in the Cornwallis watershed, but less impacted by human activity (Brisbois et al. 2008). The water quality assessed by the FBI indicated that water quality at this site was excellent to very good while this index showed the water quality in Thomas Brook to be more variable, which they attributed to stream bed and canopy differences in Thomas Brook and human influences. The other macroinvertebrate metrics $($ mean $\% \mathrm{EPT}=55.8 \%$ and mean $\%$ Chironomidae $=18.0 \%)$ confirmed better water quality in Sharpe Brook compared to Thomas Brook (Brisbois et al. 2008). The invertebrate metric values for Thomas Brook herein are more like those for Sharpe Brook reported by Brisbois et al (2008).

Hilsenhoff's Family Biotic Index (FBI) was calculated for three stream sites (on collection dates where there was a range of between 100-200 invertebrates collected) (Hilsenhoff 1988). The mean FBI was used as an indicator for water quality as described in Hilsenhoff (1988); water quality at site 1 was rated excellent all year, mean $\mathrm{FBI}=2.6 \pm 0.8$, Sites 2 and 4 were very good averaged over the year (3.9 \pm 1.3 and $4.1 \pm 1.0$, respectively) (Table 2$)$. However, Site 2 water quality was good in May and June but only fair in July and Site 4 (ditch) 
was fair in March but good in May and excellent in the winter months (Table 2). According to Brisbois et al. (2008) the FBI at a site (\#2) near the top of the watershed was excellent in May and Sept and their site 3 was good all year. Their site 4 in the middle of the watershed, which is in the same area as my site 2, was rated as having good water quality in Sept but was fair to poor in May and July (Brisbois et al. 2008). My data from this region of the watershed suggested water quality was good in May but, like the Brisbois study, water quality was lower in July (Table 2).

According to the invertebrate metrics calculated for Thomas Brook in this study the water quality overall was good with some variability between sites over the year (Table 2 and Fig. 5). The lowest \%EPT and highest \%Chironomidae at the three stream sites in the current study was at site 2, midway down the watershed and nearest to the most intensive farming area (Fig. 5). The water quality evaluation (WQE) based on FBI calculated for site 2 was good to excellent most of the year but only fair in July. Water quality was only fair in March at site 4 based on the FBI and good to excellent the rest of the year (Table 2). There was little evidence of impairment in Thomas Brook now compared to the water quality described by Brisbois et al. (2008).

\section{Diversity of trichomycetes}

Trichomycetes are obligate colonizers of the gut of herbivorous insect hosts and they show a degree of host specificity, at least at the ordinal level (Lichtwardt et al. 2001). Trichomycetes are found in the gut where materials ingested are concentrated, and as absorptive heterotrophs they may be susceptible to pollutants that also affect water quality. It is unknown if or how water quality may influence the trichomycete community structure (presence/abundance) in the gut of their hosts. There were 34 species collected from all hosts at the four sites over the 16-month collection period (Table 1). To eliminate potential bias due to habitat preference and 
seasonality of different insect hosts, only Ephemeroptera and Diptera were selected to examine trichomycete community structure related to water quality evaluation because these hosts were available at all sites and throughout the whole collection period.

Figure 6 shows the number of mayfly nymphs and dipteran larvae dissected and the number with trichomycetes in the gut, shown as percentage. Trichomycete taxa richness in dipterans was 10, 15 and 14 at sites 1,2 , and 4 . Sites 1 and 2 had 5/20 taxa in common, sites 1 and 4 also shared 5/21 taxa while sites 2 and 4 shared 10/20 taxa in the guts (Table 1). All the sites were separated by over $1 \mathrm{~km}$ (Fig. 1B) but there is little published information available to determine if downstream migration of fungal spores or colonized insects could explain the constitution of the trichomycete community at sites along the brook.

The trichomycete colonization in mayflies was generally lower than in dipterans at the sites and the taxa composition in mayflies was much lower than in dipterans, with only three taxa recorded and the only shared trichomycete in mayfly nymphs among the three sites was Paramoebidium spp. (Table 1). At site 3 (pond) 59 mayfly nymphs were collected in 2011/2012 and 55 were dissected but none were colonized by trichomycetes. There were some midges (Diptera:Chironomidae) dissected from the pond and most had trichomycetes in the gut (Fig. 7C).

Colonization of mayflies by trichomycetes was lowest at site 1 and prevalence of gut microbes was low in both mayflies and dipterans at site 4 (Fig. 6). Insects dissected from Site 2 had high prevalence of trichomycetes with $72.5 \%$ of mayflies and $91.7 \%$ of the dipterans dissected colonized by trichomycetes (Fig. 6). This site had poorer water quality than sites 1 and 4, for at least part of the year, according to the invertebrate metrics (Fig. 5 and Table 2). 
Few dipterans were collected at site 1, where water quality was best and human impact was likely less, but trichomycetes were found in $94.4 \%$ of these hosts dissected at this site (Fig.6). WQE based on FBI at site 1 was excellent over the whole collection period. (Table 2). The abundance of dipterans at site 1 was low but consistent throughout the collection period and the colonization of dipteran guts was uniformly high with most insects having trichomycetes (Fig. 7A).

Site 2 had more dipterans dissected than site 1 and, like at site 1, there was a high prevalence of trichomycetes in these hosts (91.7\%) (Fig. 6). WQE at site 2 was also good to excellent for most of the year but only fair in July (Table 2). Interestingly, this coincided with a higher abundance of dipterans (mostly chironomids) collected and dissected but also a high prevalence of trichomycetes was seen in July (Fig. 7B). In the pond (site 3) the largest numbers of dipterans collected were in June and July and the prevalence of trichomycetes in the guts of these hosts was also high (Fig 7C).

Dipterans dissected at site 4 were comparable to site 2 but trichomycete prevalence was lower at site 4 (Fig. 6). The numbers collected and dissected were highest in Apr and May at site 4 but the prevalence of trichomycetes was lower at this time, and in Sept, than through the summer months (Fig. 7D). The WQE at this site was fair in Mar but good to excellent the rest of the year so water quality may have affected trichomycete colonization early in the year (Table 2).

The pattern of trichomycete colonization of mayfly nymphs is harder to discern. There were only three trichomycetes recorded from mayflies at all three stream sites (Paramoebidium spp, Glotzia gemina R.T. William and Strongman (five collections at one site) and Graminella microspora (1 collection). Paramoebidium spp. accounted for nearly all the trichomycete records at the stream sites. The prevalence of Paramoebidium spp. is quite high in the mayflies dissected 
with a few exceptions: Apr/May and Aug at site 1, July at site 2 and in June-Sept collections at site 4 (Fig. 8 A, B and C). No mayflies from the pond site (site 3) had trichomycetes. Like in the dipterans, trichomycete colonizations correlated to WQE with the periods where the FBI showed reduced water quality coinciding with fewer trichomycetes present.

\section{Discussion}

Remediations occurred in the Thomas Brook watershed between 2004 and 2008 (AAFC \# 10317E 2008). Brisbois et al. (2008) measured water quality while the remediation efforts were in progress (May-Sept 2006). My collections were made Apr 2011-Aug 2012. The higher the $\%$ EPT the better the water quality. The $\% \mathrm{EPT}$ in my collections suggest better water quality in Thomas Brook compared to the measurements by Brisbois et al. (2008) and were slightly higher than the \%EPT calculated for the less impacted site, Sharpe Brook (55.8\%). The FBI in the sampling for this study in 2011/2012 showed excellent to good WQE with only fair quality at site 2 in July and at site 4 in March. The Brisbois collections in 2006 reported variable WQE in Thomas Brook, depending on the month the sampling was done (Brisbois et al. 2008). The insect metrics reported here suggest that remediation efforts in Thomas Brook may have improved water quality since the Brisbois study.

There were 34 species of trichomycetes recorded in all hosts over the 16 month collection period with two new species described from Thomas Brook and the known geographic distribution record for seven species was expanded (Table 1). These results are like other inventories from streams in NS (White and Strongman 2012a 2012b, William and Strongman 2013a 2013b), and demonstrate that the diversity of trichomycetes is high in NS but there are likely many more species to discover. 
Other studies have provided some data on the prevalence of trichomycetes in their hosts (Beard and Adler 2002, William and Strongman 2013a, Strongman and White 2019). In the current study trichomycete colonization of dipterans (black flies and midges) and mayflies (several families) was examined in the context of water quality measured by typical invertebrate metrics (FBI, \%EPT and \%Chironomidae). The three stream sites along Thomas Brook also varied in their riparian characteristics as well as the potential degree of impact from human activity.

The comparison of trichomycete taxa in dipterans recovered from the three stream sites showed there were few taxa shared although there were nearly the same number of taxa seen at each pair of sites $(5 / 20,5 / 21$ and 10/20 Table 1$)$. This may be explained by some level of site specificity related to stream characteristics or just to a very high number of trichomycetes that are rare in the system. The water quality measures used suggested site 2 was poorer (based on $\%$ EPT and \%Chironomidae) and WQE in July was only fair but there was no apparent effect on the trichomycete prevalence in dipterans at this site over the period (Fig. 7B). Site 4 had fair WQE in March and the trichomycete prevalence in Apr and May at this site was lower than in the summer but also in Sept when water quality was better (Fig. 7D). Sites 2 and 4 where WQE was poorer at times coincided with lower diversity of trichomycetes but over the whole collection period it appears the system was resilient and trichomycetes rebounded so periods of poorer water quality did not seem to affect the population within the system even though riparian characteristics and human inputs varied from top to bottom of the watershed. Dipterans, especially chironomids are known to be tolerant of poor water quality and the data suggest that overall the trichomycetes in their guts are also tolerant, although water quality at these sites was good to excellent most of the year (Fig.5, Table 2). 
There are nine genera and 68 species of harpellid trichomycetes described from several families of Ephemeroptera and the protistan Paramoebium spp. is also very common in guts of mayfly nymphs (Lichtwardt et al. 2001). Paramoebidium spp. were common but the near absence of harpellid species in the mayflies from Thomas Brook is surprising. Inventories done at other sites in NS recorded up to five species of harpellid fungi in mayfly nymphs and Paramoebium spp. were common too (White and Strongman 2012b, William and Strongman 2013a, 2013b). A study in streams in NL reported five species of fungal trichomycetes in mayflies (Strongman 2010) and collections from Algonquin park yielded six species of harpellids in mayfly nymphs (Strongman and White 2008). The dipteran midges (Chironomidae) collected at all sites in Thomas Brook contained 18 species of harpellids and blackfly larvae (Simuliidae) had four species of harpellid fungi (Table 1). Dipteran hosts are known to contain many more species than mayflies (Lichtwardt 2004). Mayfly nymphs are more sensitive to pollution and lower water quality than chironomids so one possible explanation for the lack of mayfly gut fungi could be that they were affected by water quality although it was not poor enough to impact the mayfly population. This is speculative because absence of harpellid trichomycetes is not strong data to support this interpretation, but it is possible that fungal trichomycetes may be affected earlier by pollutants than their host. Extensive studies in systems before and after remediation of human impact might provide more data on the significance of gut fungi as early indicators of pollution effects in aquatic systems.

\section{Acknowledgments}

I thank Dale Hebb and Dr. Debbie Moreau Agriculture and Agri-food Canada, Kentville research Station, Kentville, NS for introducing me to the Thomas Brook project. Saint Mary's University 
Graduate Studies and Research provided some funding for travel to the sites. Thanks to Carolyn

Bird, Chester Basin, NS for much appreciated advice on the Latin naming of the new species.

\section{References}

AAFC \#10317. 2008. The watershed evaluation of beneficial management practices (WEBs). Available at: http://www.nsfa-fane.ca/efp/wpcontent/uploads/2014/07/watershedevaluat10317cana.pdf [accessed 24 Feb 2021].

Beard, C.E., and Adler, P.H. 2003. Seasonality of trichomycetes in larval black flies from South Carolina, U.S.A. Mycologia, 94: 200-209. doi:10.1080/15572536.2003.11833225. PMID: 21156489.

Brisbois, M.C., Jamieson, R., Gordon, R., Stratton, G, and Madani, A. 2008. Stream ecosystem health in rural mixed land-use watersheds. J. Environ. Eng, Sci. 7: 439-452.

Crawford, J.K. and Lenat, D.R. 1989. Effects of Land Use on the Water Quality and Biota of Three Streams in the Piedmont Province of North Carolina. U.S. GEOLOGICAL SURVEY Water-Resources Investigations Report 89-4007.pg. 67.

Ferrington Jr., L. C., Lichtwardt, R. W., and Hayford, B. 2000. Smittium gravimetallum (Trichomycetes: Harpellales), a new species of gut fungus from Dicrotendipes fumidus (Johannsen) (Diptera: Chironomidae) in a metal-polluted stream. In: Late 20th. Century Research on Chironomidae: an Anthology from the 13th International Symposium on Chironomidae. O. Hoffrichter, ed., Shaker Verlag, Aachen. pp. 253-257.

Herman, M.R., and Nejadhashemi, A.P. 2015. A review of macroinvertebrate and fish-based stream health indices. Ecohydrology \& Hydrobiology, 15: 53-67.

Hilsenhoff, W.L. 1988. Rapid field assessment of organic pollution with a family-level biotic index. Journal of the North American Benthological Society, 7: 65-68.

Lichtwardt, R.W. 1986. The Trichomycetes: fungal associates of arthropods. Springer-Verlag, New York.

Lichtwardt, R.W. 1994. Trichomycete fungi living in the guts of Costa Rican phytotelm larvae and other lentic dipterans. Revista de Biología Tropical 42: 31-48.

Lichtwardt, R. W. 1995. Biogeography and fungal systematics. Canadian Journal of Botany 73 (Suppl. 1): S731-S737.

Lichtwardt, R.W. 2004. Lucid keys to the Trichomycetes. Available from URL http://keys.lucidcentral.org/key-server/data/0b08020c-0f0c-4908-8807- 
030c020a0002/media/Html/index.html. These keys have been regularly updated since 2004 . [accessed 23 Feb 2021].

Lichtwardt. R.W. 2012a. Trichomycete gut fungi from tropical regions of the world. Biodiversity and Conservation 21: 2397-2402.

Lichtwardt, R.W. 2012b. Evolution of Trichomycetes. Chapter 5, p. 107-114. In Systematics and evolution of fungi, J.K. Misra, J.P. Tewari, S.K. Deshmukh, eds. 412 p.

Lichtwardt, R.W., Cafaro, M., and White, M.M. 2001. The Trichomycetes: fungal associates of arthropods. Available from https://keyserver.lucidcentral.org/key-server/data/0b08020c-0f0c4908-8807-030c020a0002/media/Html/monograph/text/mono.htm [accessed 24 Feb 2021].

Lydy, M.J., Crawford, C.G, and Frey J.W. 2000. A comparison of selected diversity, similarity, and biotic indices for detecting changes in benthic-invertebrate community structure and stream quality. Arch. Environ. Contam. Toxicol. 39: 469-479. DOI: 10.1007/s002440010129.

McCreadie, J.W., Adler, P.H. and Beard, C.E. 2011. Ecology of symbiotes of larval black flies (Diptera: Simuliidae): Distribution, diversity, and scale. Environ. Entomol. 40(2): 289-302. DOI: 10.1603/EN10258.

Nelder, M.P., Beard, C.E., Adler, P.H , Kim, S.-K. And McCreadie, J.W. 2006. Harpellales (Zygomycota: Trichomycetes) associated with black flies (Diptera: Simuliidae): world review and synthesis of their ecology and taxonomy. Fungal Diversity 22: 121-169.

Merritt R.W., and Cummins K.W. 1996. An introduction to the aquatic insects of North America. 3rd ed. Dubuque, Iowa: Kendall/Hunt Publishing Co.

Reeves, W.K. 2004 Temporal distribution of Smittium culisetae in a wild population of Wyeomyia smithii from pitcher plants, Mycologia 96(6): 1233-1235.

DOI:10.1080/15572536.2005.11832872.

Strongman, D.B. 2010. Trichomycetes from Newfoundland, including Gros Morne National Park. Botany 88(12): 1011-1022. doi:10.1139/B10-073.

Strongman, D.B., and White, M.M. 2008. Trichomycetes from lentic and lotic aquatic habitats in Ontario, Canada. Botany 86(12): 1449-1466. doi:10.1139/B08-107.

Strongman, D.B. and White, M.M. 2019. New species and geographical distribution of trichomycetes (gut fungi) in a novel host, caddisfly (Trichoptera). Botany 97: 537-545. doi:10.1139/cjb-2019-0

White, M.M. and Strongman, D.B. 2012a. New species of Smittium and Stachylina and other trichomycetes in larval Diptera from streams in Nova Scotia, Canada. Botany 90(12): 1204-1219. doi: 10.1139/b2012-081 
White, M.M. and Strongman, D.B. 2012b. New species of Spartiella and Legeriosimilis and other arthropod-associated trichomycetes from Nova Scotia, Canada. Botany 90(12): 1195-1203. doi: 10.1139/b2012-080

White, M.M., Valle, L.G., Lichtwardt, R.W., Siri, A., Strongman, D.B., William, R.T., Gause, W.J., and Tretter, E.D. 2018. New species and emendations of Orphella: taxonomic and phylogenetic reassessment of the genus to establish the Orphellales, for stonefly gut fungi with a twist. Mycologia 110: 147-178. doi.org/10.1080/00275514.2018.1448198

William, R.T., and Strongman, D.B. 2013a. Trichomycetes associated with insects in lotic habitats (streams) within the Halifax Regional Municipality, Nova Scotia, Canada. Botany 91(6): 368-381. doi:10.1139/cjb-2012-0237.

William, R.T., and Strongman, D.B. 2013b. Trichomycetes occurring in both lentic (lake) and lotic (stream) habitats within the Halifax Regional Municipality, Nova Scotia Canada. Botany 91: 382-402. doi:10.1139/cjb-2012-0238.

William, R.T. and Strongman, D.B. 2013c. Trichomycetes from Governor's Lake and Lake Micmac within the Halifax Regional Municipality, Nova Scotia, Canada. Botany 91: 360-367. doi:10.1139/cjb-2012-0236

Wilson E.R., Smalling K.L. Reilly T.J., Gray E., Bond L., Steele L., Kandel P., Chamberlin A., Gause J., Reynolds N., Robertson I., Novak S., Feris K., White M.M. 2014. Assessing the potential effects of fungicides on nontarget Gut Fungi (Trichomycetes) and their associated larval black fly hosts. Journal of the American Water Resources Association 50: 420-433.

Figure captions.

Figure 1. (A) Cornwallis watershed in the Annapolis Valley, Nova Scotia Thomas Brook watershed outlined in white, top left. (B) Thomas Brook watershed showing the location of collection sites. Maps from AAFC \# 10317E 2008. Contains information licensed under the Open Government Licence - Canada.

Figure 2. Smittium scrobense sp. nov. (A) Young thalli with trichospores. Arrow shows bulbous secreted holdfast. (B) Mature thallus with basal holdfast and secreted material (black arrow), and a released trichospore (white arrow). (C) Young thallus with trichospores attached. Arrow shows slightly swollen basal holdfast. (D) Mature trichospores with a collar (arrows). Scale bars $=20$ $\mu \mathrm{m}$.

Figure 3. Stachylina stagnicola sp. nov. (A) Mature thallus with secreted holdfast material (arrow) and attached trichospores. (B) Thallus and trichospores, one trichospore released showing short collar and single appendage (arrow). Scale bars $=20 \mu \mathrm{m}$.

Figure 4. Trichomycete species that are new Canadian geographic distribution records in Thomas Brook. Smittium caribense. (A) Trichospores. (B) Trichospores and swollen basal holdfast cell 
(arrow). Pennella angustisporum. (C) Thallus with cylindrical trichospores (arrow). (D) Digitate basal holdfast (arrow). (E) Single released trichospore. Pseudoharpella arcolamylica. (F) Holdfast and basal branches. (G) Released trichospore with two of the three appendages (arrows) visible. $(\mathrm{H})$ Fertile branches with helical trichospores attached (arrows). Scale bars $=20 \mu \mathrm{m}$.

Figure 5. Invertebrate metrics used to measure water quality at each of the sampling sites in Thomas Brook. \%EPT is percentage Ephemeroptera, Plecoptera and Trichoptera. The sites listed are described in the Materials and Methods section.

Figure 6. Number of mayfly nymphs (Ephems) and dipteran larvae (Dips) dissected and number colonized by trichomycetes (\# with Trichos) at three stream sites in Thomas Brook. Percentages indicate the number of dissected hosts that had trichomycetes.

Figure 7. Number of dipteran larvae dissected and the number with trichomycetes (\# with trichs). (A) Number of trichomycetes collected by month at site 1. (B) Number of trichomycetes collected by month at site 2. (C) Number of trichomycetes collected by month at site 3 (pond). (D) Number of trichomycetes collected by month at site 4 .

Figure 8, Number of mayfly nymphs dissected with trichomycetes (\# with trichs). (A) Number of trichomycetes collected by month at site 1. (B) Number of trichomycetes collected by month at site 2. (C) Number of trichomycetes collected by month at site 4 . There were no trichomycetes seen from the pond (site 3) collections. 
Table 1. Trichomycete species collected and the number of species from all hosts at four sites in Thomas Brook, Nova Scotia.

Orders and species

\section{Site}

Host $\quad 1^{*} \quad$ Site 2 Site $3 \quad$ Site 4

Amoebidiales

Paramoebidium spp.

Mayfly, black fly, stonefly, caddisfly $\quad \mathrm{x} \quad \mathrm{x} \quad \mathrm{X} \quad \mathrm{x}$

Paramoebidium cassidula

Stonefly $\mathrm{x} \quad \mathrm{x}$

Paramoebidium curvum

Black fly $\quad \mathrm{x} \quad \mathrm{x}$

X

Asellariales

Orchesellaria sp.

Springtail

(Collembola) $\quad \mathrm{x}$

Eccrinales

Enterobryus euryuri**

Millipede (Diploda) X

Harpellales

Ejectosporus trisporus

Stonefly

X

Genistellospora homothallica***

Black fly

X

$\mathrm{X}$

Genistelloides hiburnus

Stonefly $\quad \mathrm{x}$

Glotzia gemina

Mayfly

$\mathrm{X}$

Graminella microspora****

Mayfly $\quad \mathrm{x}$

Harpella melusinae

Black fly $\quad \mathrm{x}$

X

X

Lancisporomyces anguilliformis

Stonefly

$\mathrm{X}$

Lancisporomyces nemouridarum

Pennella angustispora**

Stonefly $\mathrm{x}$

Black fly $\quad \mathrm{x}$

X

Pseudoharpella arcolmylica**

Smittium adaiosporum

Midge (Dixidae) $\quad$ x

Midge

(Chironomidae) $\mathrm{x}$

Midge

Smittium alpinum***

(Chironomidae)

X

Midge

Smittium caribense**

(Chironomidae)

X

Midge

Smittium colboi

(Chironomidae)

Midge

Smittium cryptancora

(Chironomidae)

X $\quad$ X

X

X

X 
Midge

Smittium culicis

(Chironomidae)

$\mathrm{X}$

Midge

Smittium pavocaudata

(Chironomidae)

$\mathrm{X}$

$\mathrm{X}$

Smittium radiculans

Midge

(Chironomidae) $\mathrm{x} \quad \mathrm{x}$

Midge

Smittium scrobense

(Chironomidae)

$\mathrm{X}$

$\mathrm{X}$

$\mathrm{X}$

Smittium simulii

Black fly, midge

(Chironomidae)

midge

Stachylina brevicellaris

(Chironomidae)

X $\quad \mathrm{X}$

midge

Stachylina grandispora

(Chironomidae)

midge

Stachylina nana

(Chironomidae)

$\mathrm{X}$

midge

Stachylina pedifer

(Chironomidae)

midge

Stachylina somnisimilis

(Chironomidae)

X $\quad \mathrm{X}$

Stachylina stagnicola

midge

(Chironomidae)

X $\quad$ X

Stachylina subgrandis

midge

(Chironomidae)

X $\quad \mathrm{X} \quad \mathrm{X}$

$\mathrm{X}$

Orphellales

Orphella avalonensis

Stonefly $\mathrm{x}$

Orphella dalhousiensis

Stonefly $\mathrm{X}$

Number of species

15

18

11

14

* Site 1 is at Thomas Brook origin, Site 2 is midway along stream in an agricultural area, Site 3 is an

irrigation pond next to Site 2, Site 4 is a ditch near where Thomas Brook ends.

$\mathrm{X}$ indicates that the species was present at the site.

** new to Atlantic Canada

*** ON only other Canadian record (Strongman and White 2008)

**** NL only other Canadian record (Strongman 2010) 
Table 2. Family biotic index (FBI) and water quality evaluation (WQE) for 3 sites in Thomas Brook.

\begin{tabular}{|c|c|c|c|c|c|c|c|c|}
\hline Site 1 & FBI & WQE & Site 2 & FBI & WQE & Site 4 & FBI & WQE \\
\hline 4 Jan 2012 & 2.6 & excellent & 4 Jan 2012 & 1.64 & excellent & 23 Mar 2012 & 5.19 & fair \\
\hline 28 Jan 2012 & 2.92 & excellent & $23 \operatorname{Mar} 2012$ & 3.14 & excellent & 9 May 2011 & 4.9 & good \\
\hline 9 May 2011 & 3.74 & excellent & 11 May 2012 & 4.5 & good & 24 May 2011 & 4.52 & good \\
\hline 24 Jun 2012 & 2.3 & excellent & 4 Jun 2012 & 4.94 & good & 5 Jul 2011 & 3.98 & very good \\
\hline 9 Nov 2011 & 1.41 & excellent & 13 Jun 2011 & 3.84 & very good & 9 Nov 2011 & 2.62 & excellent \\
\hline $2 \operatorname{Dec} 2011$ & 2.58 & excellent & $26 \mathrm{Jul} 2011$ & 5.19 & fair & 2 Dec 2011 & 3.44 & excellent \\
\hline $\operatorname{Avg} \pm \mathrm{SD}$ & $2.6 \pm 0.8$ & & & $3.9 \pm 1.3$ & & & $4.1 \pm 1$ & \\
\hline
\end{tabular}

FBI range and water quality evaluations are from Hilsenhoff (1988). 


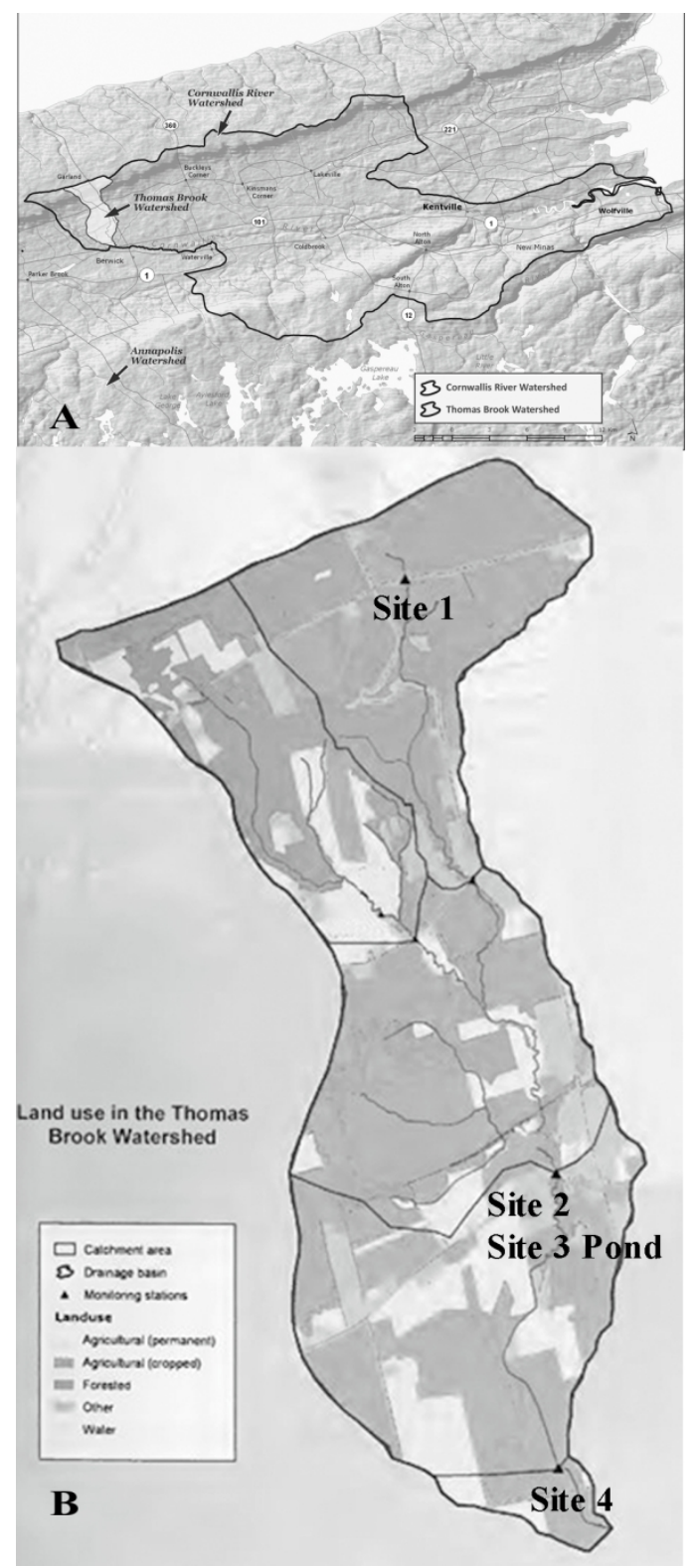

Figure 1. (A) Cornwallis watershed in the Annapolis Valley, Nova Scotia Thomas Brook watershed outlined in white, top left. (B) Thomas Brook watershed showing the location of collection sites. Maps from AAFC \# 10317E 2008. Contains information licensed under the Open Government Licence - Canada. 


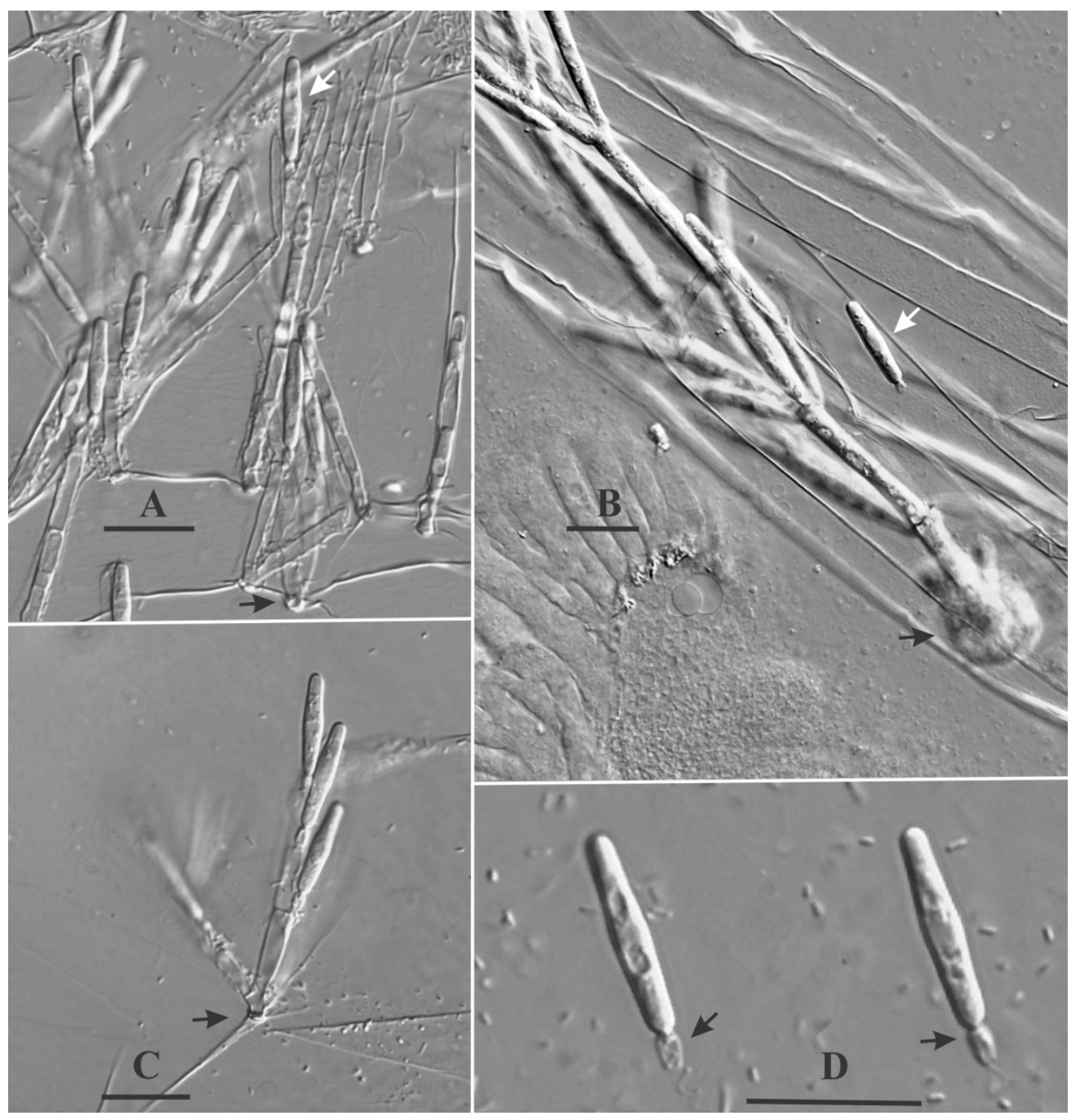

Figure 2. Smittium scrobense sp. nov. (A) Young thalli with trichospores. Arrow shows bulbous secreted holdfast. (B) Mature thallus with basal holdfast and secreted material (black arrow), and a released trichospore (white arrow). (C) Young thallus with trichospores attached. Arrow shows slightly swollen basal holdfast. (D) Mature trichospores with a collar (arrows). Scale bars $=20 \mu \mathrm{m}$. 


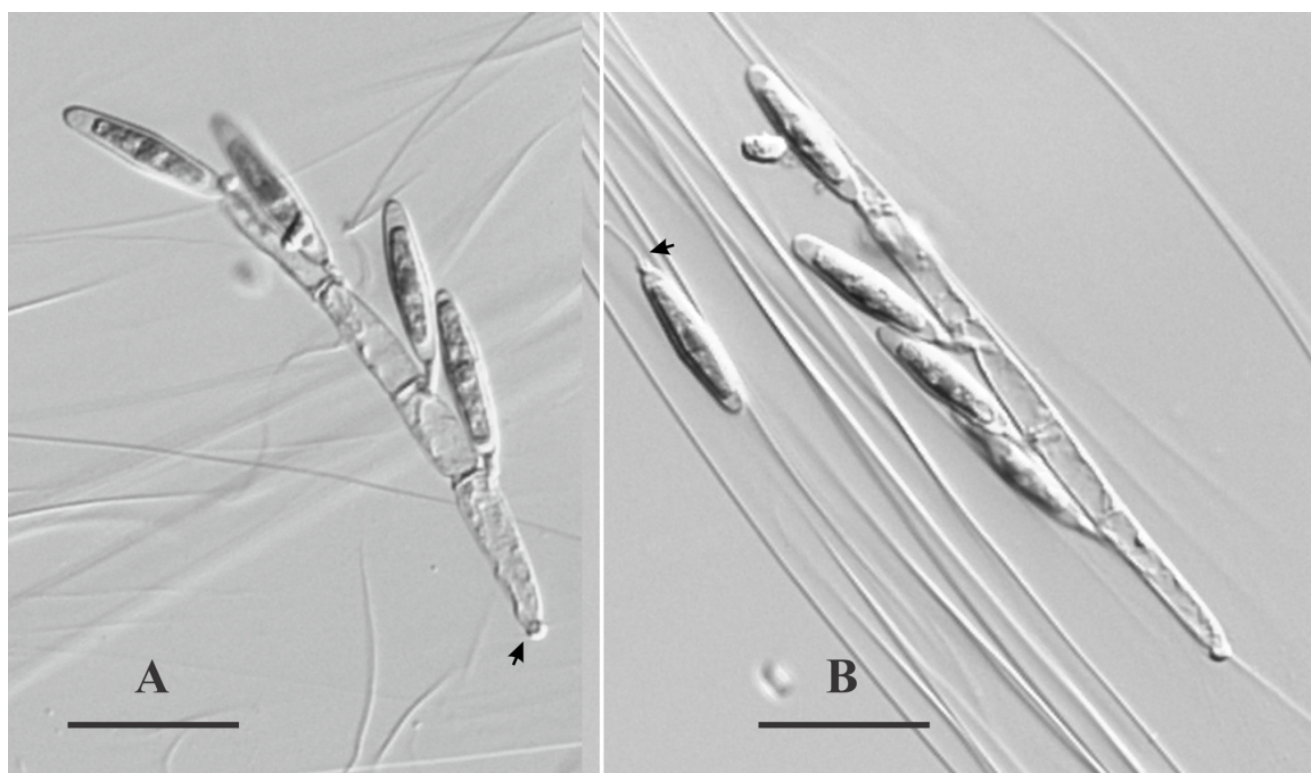

Figure 3. Stachylina stagnicola sp. nov. (A) Mature thallus with secreted holdfast material (arrow) and attached trichospores. (B) Thallus and trichospores, one trichospore released showing short collar and single appendage (arrow). Scale bars $=20 \mu \mathrm{m}$. 

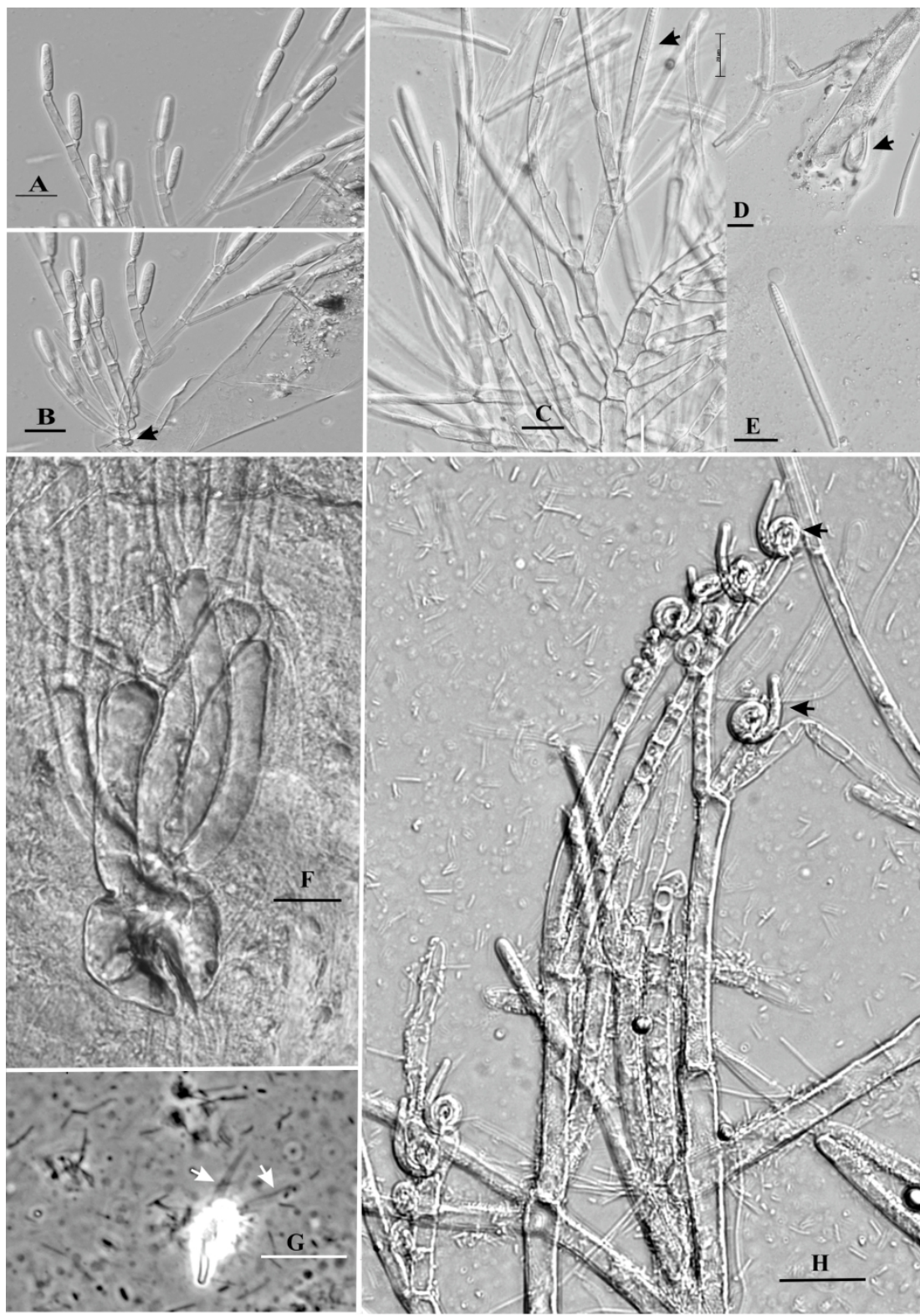

Figure 4. Trichomycete species that are new Canadian geographic distribution records in Thomas Brook. Smittium caribense. (A) Trichospores. (B) Trichospores and swollen basal holdfast cell (arrow). Pennella angustisporum. (C) Thallus with cylindrical trichospores (arrow). (D) Digitate basal holdfast (arrow). (E) Single released trichospore. Pseudoharpella arcolamylica. (F) Holdfast and basal branches. (G) Released trichospore with two of the three appendages (arrows) visible. $(\mathrm{H})$ Fertile branches with helical trichospores attached (arrows). Scale bars $=20 \mu \mathrm{m}$. 


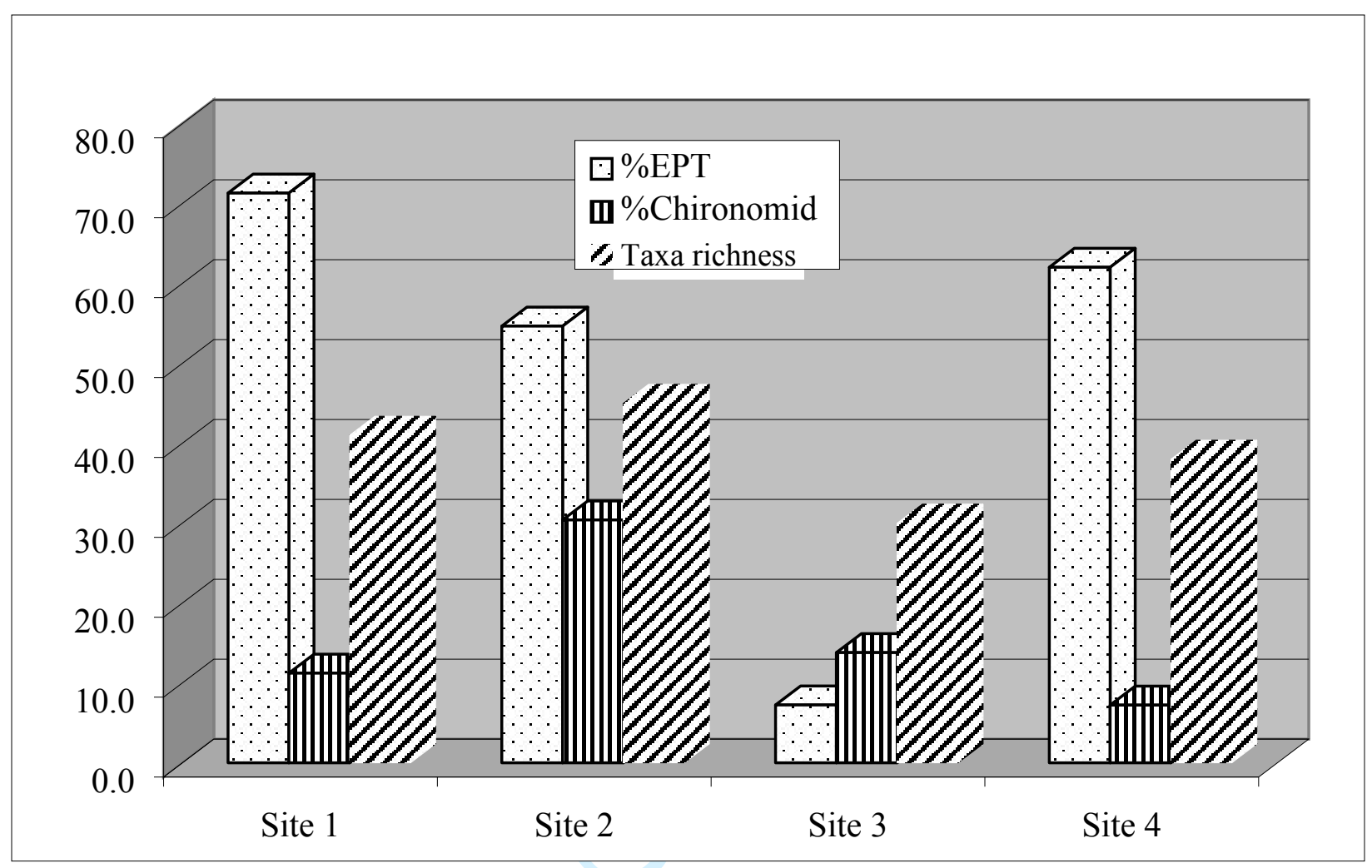




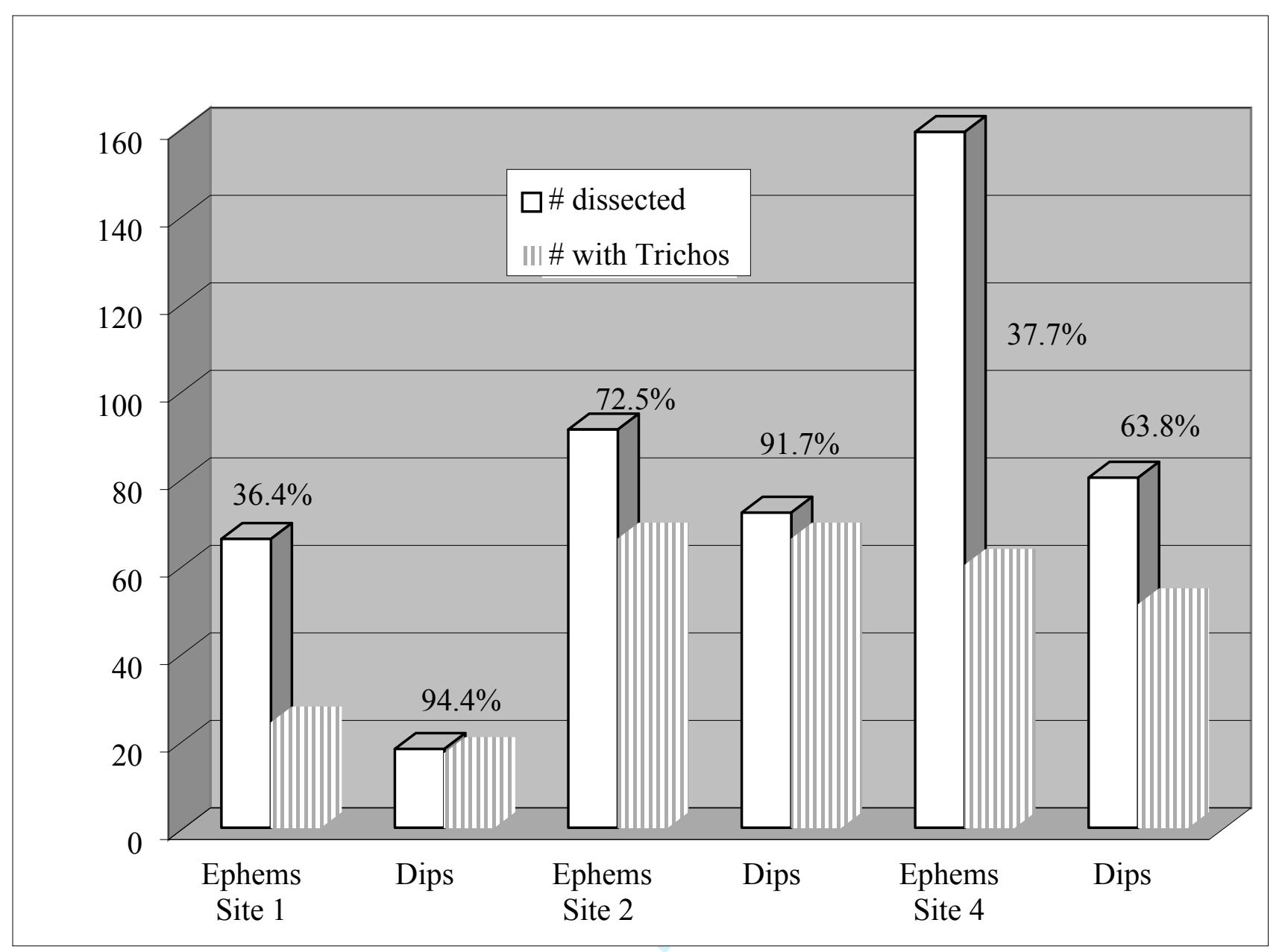



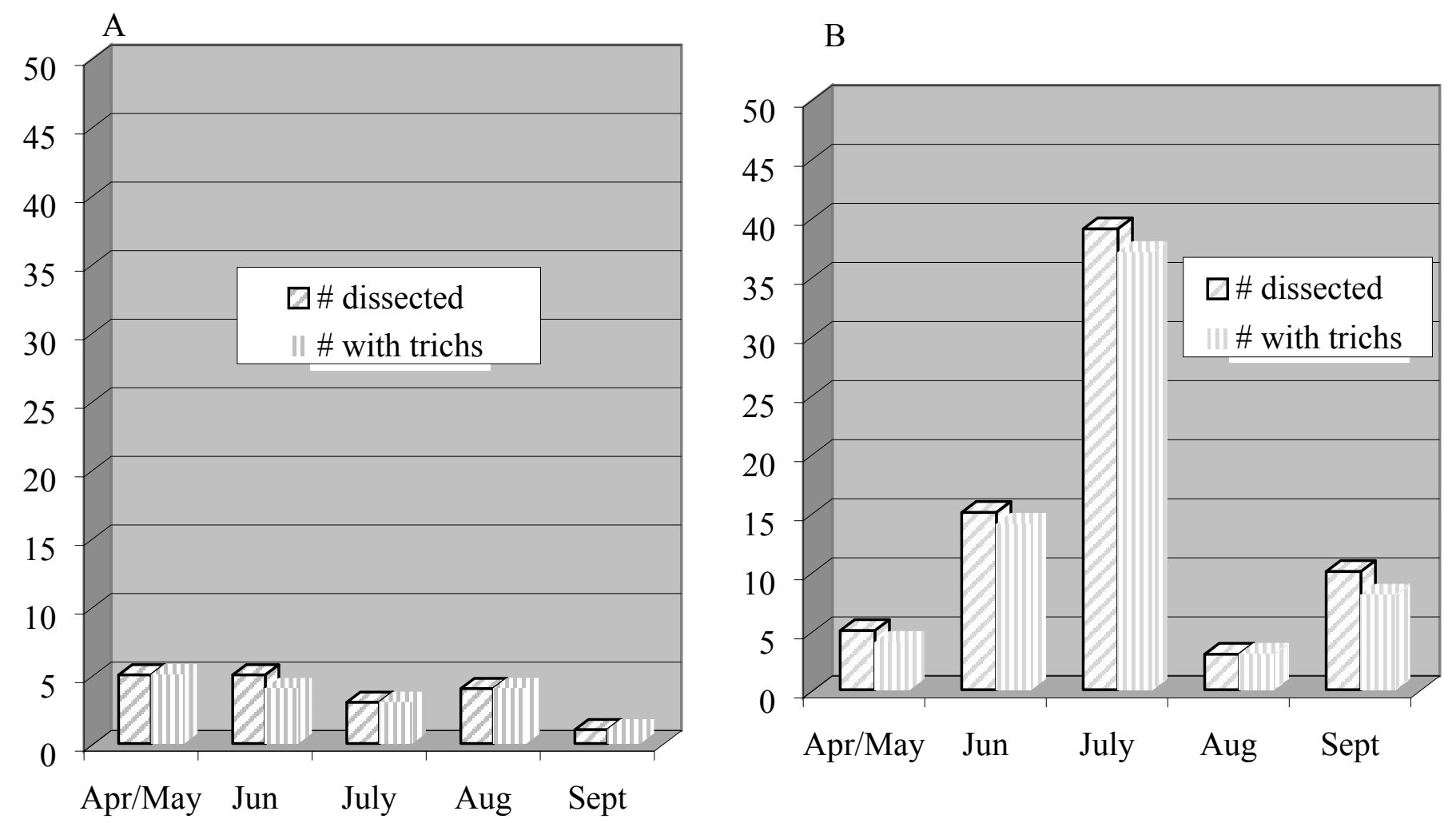

$\mathrm{C}$

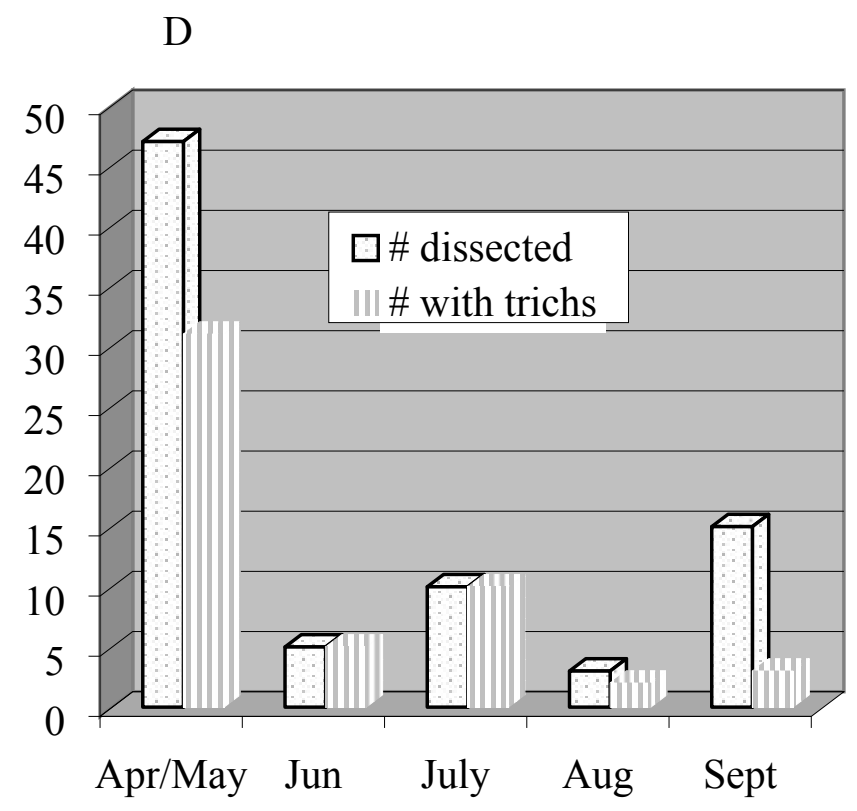


A

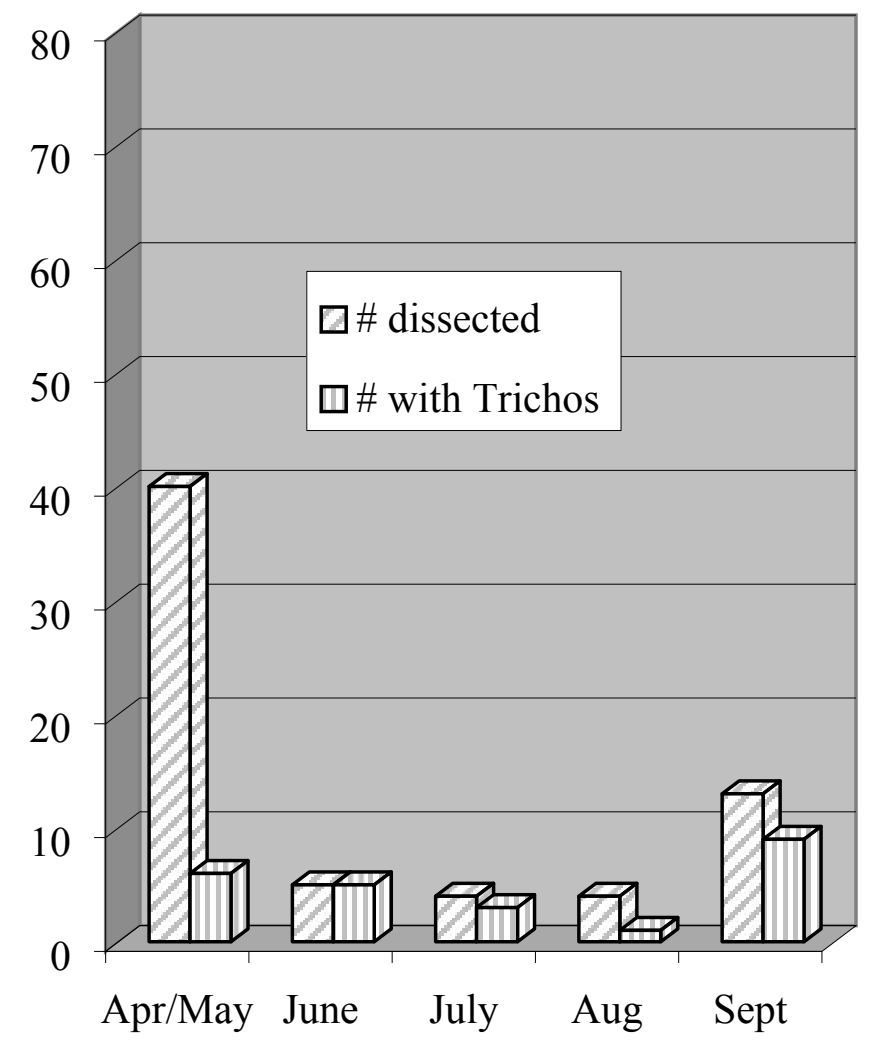

C

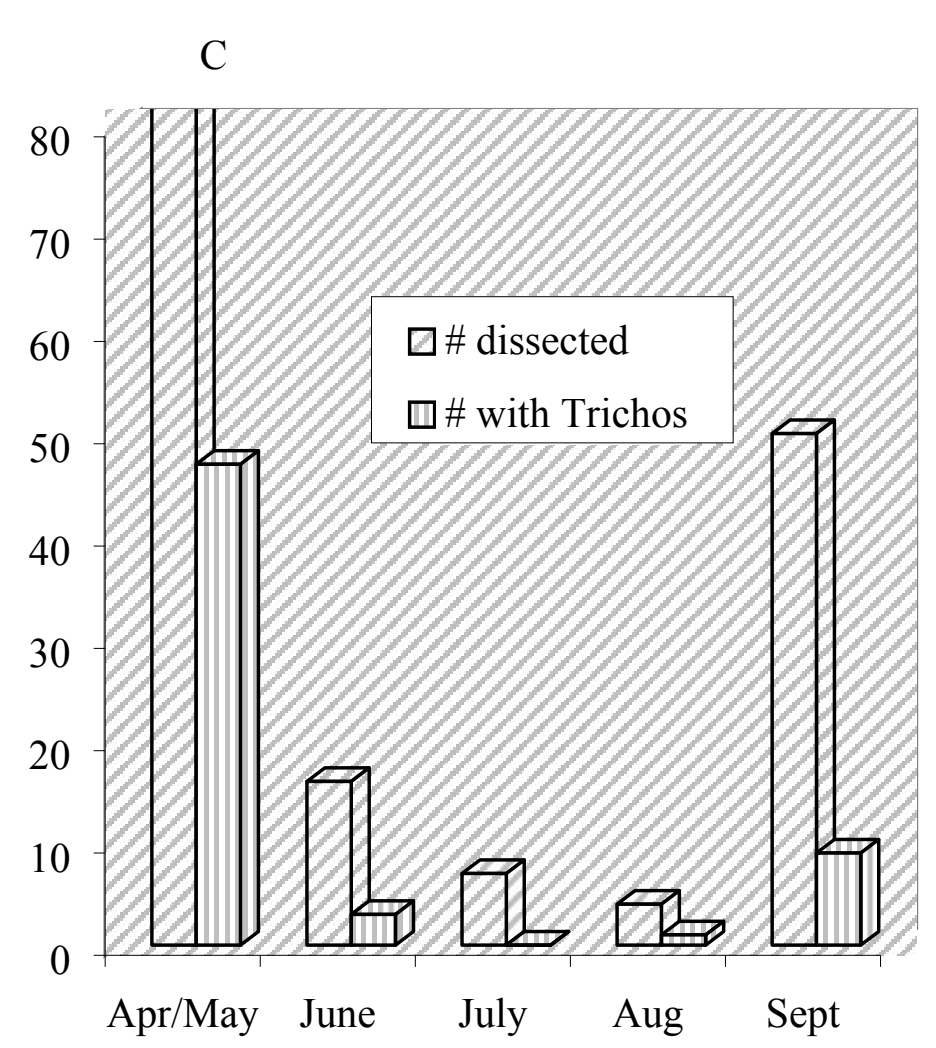

B

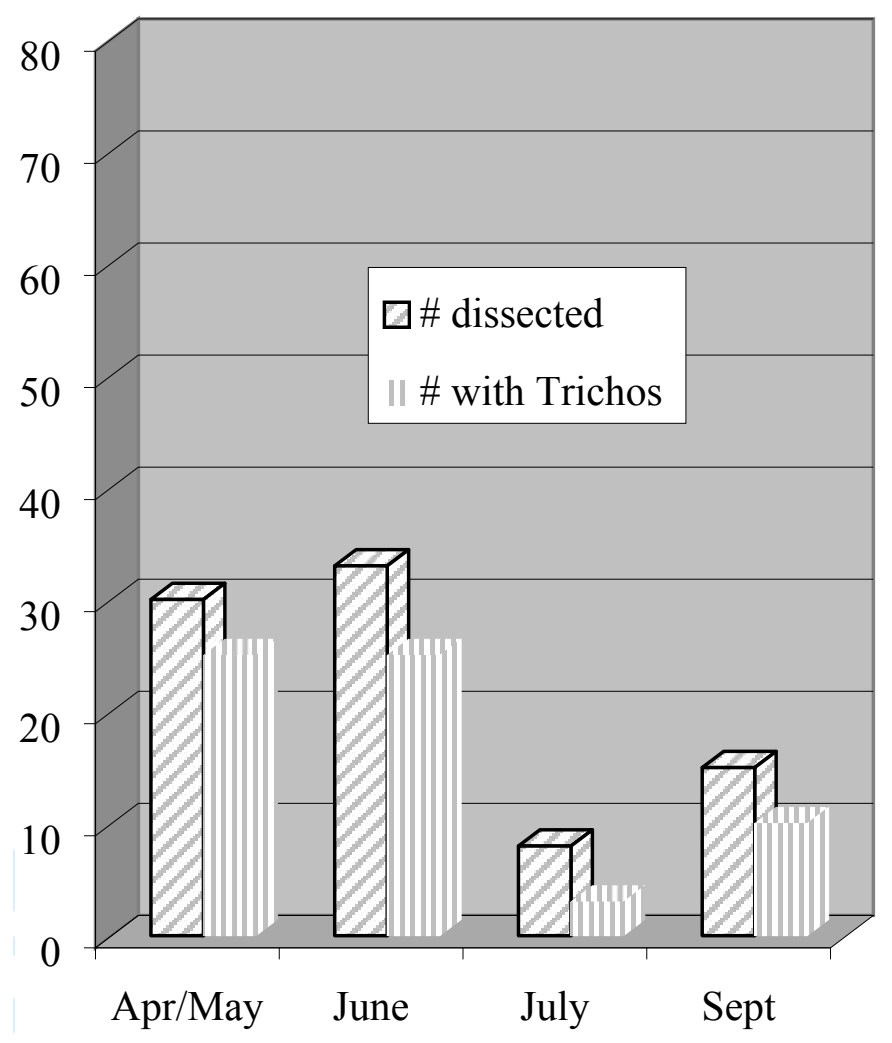

